\title{
Vascular Pattern of Chorionic Blood Vessels of Placenta and its Correlation with the Birth Weight of Neonate
}

\author{
Patrón Vascular de los Vasos Sanguíneos Coriónicos de la Placenta \\ y su Correlación con el Peso al Nacer del Recién Nacido
}

"Ranjana Verma; ${ }^{* *}$ Renu Prasad; ${ }^{* * *}$ Sabita Mishra \& ${ }^{* * * *}$ Jagat Mohini Kaul

VERMA, R.; PRASAD, R.; MISHRA, S. \& KAUL, J. M. Vascular pattern of chorionic blood vessels of placenta and its correlation with the birth weight of neonate. Int. J. Morphol., 30(3):952-955, 2012.

SUMMARY: Two hundred fresh full term placentae of normal pregnancies were collected from the department of Obstetrics and Gynaecology, RIMS, Ranchi, Jharkhand, India to observe the incidence of vascular pattern of chorionic blood vessels of placenta and to note the relationship between vascular pattern of placenta and the birth weight of neonate. Dye was injected into umbilical vessels under normal physiological pressure and diameter of chorionic blood vessels were taken at the centre and periphery. Two types of vascular pattern of chorionic blood vessels of placentae were observed- Dispersal and Magistral. Dispersal pattern was found in 63\% cases and magistral pattern was observed in $37 \%$ cases. An interesting observation was noted that the birth weight of neonate was higher in magistral pattern in comparison to dispersal pattern in both sexes.

KEY WORDS: Placentae; Vascular pattern; Chorionic blood vessels; Birth weight; Neonate.

\section{INTRODUCTION}

Placenta is a choriodecidual structure, developing during pregnancy and carries vital functions of the foetus such as respiration, nutrition and excretion. Its foetal surface is covered with smooth glistening membrane, amnion, which can be easily stripped upto the umbilical cord. The surface of chorion thus exposed is also smooth and running in between its two layers are the branches of umbilical vessels called chorionic vessels and are most firmly secured in place. These vessels are responsive to vasoactive substances but morphologically, histologically and functionally they are peculiar (Cunnigham et al., 2001).

Initially the arteries of human placenta is described being similar in their arrangement to the spokes of wheel (Frazer, 1923). In another study, it is explained as a star like radiation and the vessels are described as falling into primary, secondary and tertiary groups (Bacsich \& Smout, 1938). But later on, the vascular pattern of placenta is described as of two types - Magistral and Dispersal (Shordania, 1929). In the dispersal type, the umbilical vessels undergo successive divisions with gradually diminishing caliber towards periphery, giving it the star pattern, while in the magistral type, the umbilical vessels give small side branches and almost reach the placental margin without marked reduction in caliber, appearing as $\mathrm{V}$ pattern. There is no correlation observed between the vascular pattern, placental area supplied and surface anastomosis. So all arteries are considered as end arteries (Franken et al., 1958).

The incidence of dispersal pattern is $63 \%$ and that of magistral is $37 \%$ (Cunnigham et al.). There is no relationship between the vascular pattern of chorionic blood vessels of placenta and development of the foetus (Wilkins, 1954; Smart, 1962). In another study, it is described that there is a significant relationship between the pattern of branching, number of primary divisions of arteries and veins and weight of the foetus (Bhargava \& Raja, 1970; Shordania; Bacsich \& Crawford).

Till date, the study on the vascular pattern of chorionic blood vessels of placenta lagging behind and most importantly there are difference of opinions on the its relation

\footnotetext{
* Assistant Professor, Department of Anatomy, Maulana Azad Medical College, New Delhi-110002, India.

** Head of Department, Department of Anatomy, Rajendra Institute of Medical Sciences, Ranchi, Jharkhand, India.

*** Associate Professor, Department of Anatomy, Maulana Azad Medical College, New Delhi-110002, India.

***** Director Professor \& Head of Department, Department of Anatomy, Maulana Azad Medical College, New Delhi-110002, India
} 
to the foetal development. The present study aims to observe the incidence of vascular pattern of chorionic blood vessels of placenta in Indian population and to know the correlation between vascular pattern and the birth weight of neonate in both sexes which is an indicator of foetal development in normal pregnancies.

\section{MATERIAL AND METHOD}

Two hundred fresh, undamaged full term placentae of normal pregnancies were obtained from labour room of the department of Obstetrics and Gynaecology, Rajendra Institute of Medical Sciences, Ranchi, Jharkhand, India, over a span of two years. All the placentae were washed in running water. Amnion was stripped till umbilical cord. Blood clots were removed from the chorionic blood vessels, initially by digital pressure and later on by irrigation with saline under 60-80 mm hg of pressure. Water from the vessels was removed by acetone. Methylene blue was injected into the artery and eosin into the vein under normal physiological pressure of umbilical blood vessels. The injection was continued for 18-20 hrs. Diameter of the chorionic blood vessels was taken vernier caliper at the site of insertion of umbilical cord (C) and at the periphery $(\mathrm{P})$.

It was categorized into two groups on the following criteria If the ratio of diameter of chorionic blood vessels of placenta at the periphery and at the centre $(\mathrm{P} / \mathrm{C})$ is:
- Half or less than half, it is categorized into dispersal type . More than half, then it is categorized into magistral type.

Simultaneously birth weight of the neonate was also noted. Mean and standard deviation of all observations were calculated.

Mean is the arithmetic mean of all observations. Standard deviation is measure of variation. It is defined as root mean - square deviation (Park, 2002).

\section{RESULTS}

Two hundred fresh full term placentae were taken for study. After washing and injecting the dye under normal physiological pressure, diameters of chorionic blood vessels of placentae were measured. Two types of vascular pattern was observed- Dispersal and Magistral. In the dispersal pattern, diameter of chorionic blood vessels showed decreasing trend from the centre to periphery (Fig 1), while in the magistral pattern, diameter of chorionic blood vessels was almost same throughout its whole extent (Fig 2). The incidence of dispersal pattern was found in 126 (63\%) placentae and that of magistral pattern was present in 74 (37\%) placentae (Table I). In all cases, arteries and veins had a similar pattern.

Table I. Incidence of the vascular pattern of chorionic blood vessels of placenta.

\begin{tabular}{lccc} 
Vascular & \multicolumn{3}{c}{ Total number of plac entae } \\
Pattern & Male (99) & Female (101) & Total (200) n (\%) \\
\hline Dispersal & 59 & 67 & $126(63 \%)$ \\
Magistral & 40 & 34 & $74(37 \%)$ \\
\hline
\end{tabular}

Table II. Correlation of the vascular pattern of chorionic blood vessels of placenta with the birth weight of neonate.

\begin{tabular}{lcccc}
\hline Foetal birth weight $(\mathrm{kg})$ & \multicolumn{2}{c}{ Dispersal Pattern (126) } & \multicolumn{2}{c}{ Magistral Pattern (74) } \\
\cline { 2 - 5 } & Male (59) & Female (67) & Male (40) & Female (34) \\
\hline $1.5-2$ & 3 & 5 & 2 & 3 \\
$2-2.5$ & 18 & 36 & 5 & 16 \\
$2.5-3$ & 19 & 22 & 10 & 9 \\
$3-3.5$ & 10 & 3 & 16 & 4 \\
$3.5-4$ & 9 & 1 & 7 & 2 \\
Total number of placentae & 59 & 67 & 40 & 34 \\
Mean weight (kg) & 2.78 & 2.47 & 3.01 & 2.58 \\
Standard Deviation (SD) & 0.51 & 0.33 & 0.46 & 0.44 \\
\hline
\end{tabular}


The vascular pattern of chorionic blood vessels of placenta was correlated with the birth weight of neonate. Mean and standard deviation of all observations was calculated statistically. Mean birth weight of neonate in the disperal pattern was $2.78 \mathrm{~kg}$ in case of males and $2.47 \mathrm{~kg}$ in case of females while in the magistral pattern it was $3.01 \mathrm{~kg}$ in case of males and $2.58 \mathrm{~kg}$ in case of females (Table II).

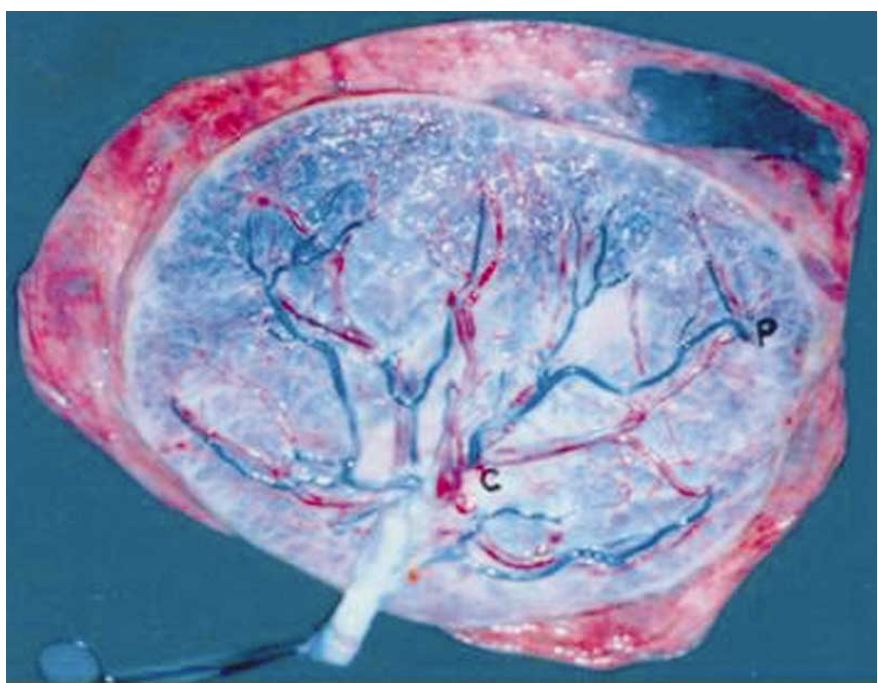

Fig. 1. Dispersal pattern of chorionic blood vessels.

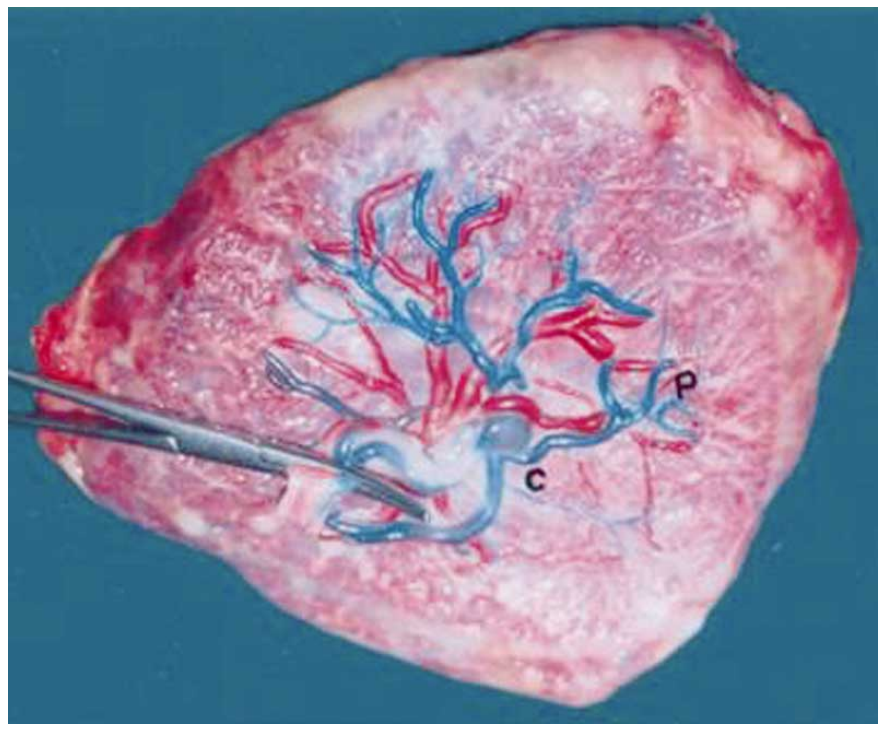

Fig. 1. Magistral pattern of chorionic blood vessels.

\section{DISCUSSION}

The placenta is a fascinating organ especially when its function is considered. During its brief intrauterine existence the foetus depends upon the placenta as its lungs, liver and kidney. Despite its unassailable role in human development, the study of placenta has lagged behind that of the foetus. A number of anatomists and embryologists worked through 1980s to provide some basic knowledge (Cunnigham et al.).

There are few studies on the vascular pattern of chorionic blood vessels of placenta. Initially the arteries of human placenta are described being similar in their arrangement to the spokes of wheel (Frazer). But later on, the vascular pattern of chorionic blood vessels of placenta is described as of two types - Magistral and Dispersal (Schordania). In the dispersal pattern umbilical vessels undergo successive divisions and rapidly diminish in caliber, while in magistral pattern umbilical vessels give side branches and the caliber of vessel is almost equal upto periphery (Franken et al.). In another study, it is observed that in the dispersal pattern, vessels undergo succession of dichotomous division and rapidly diminish in calibre and resemble in their arrangement like spokes of wheel while in magistral pattern go along with brush like vessels in cotyledon. They further held the view that vascular character of foetal placental vasculature is already recognizable at the $12^{\text {th }}$ week of pregnancy (Bacsich \& Crawford). In the present study, dispersal pattern showed successive divisions of umbilical vessels with decrease in caliber from centre to periphery while the magistral pattern showed fewer divisions of blood vessels with appreciably no decrease in diameter from centre to periphery.

The pattern of branching of blood vessel is disperse (with radiating spoke like arrangement) in $81 \mathrm{ca}-$ ses and magistral (with marginal cord attachment and vascular channels) in 86 cases (Bhargava \& Raja). The incidence of dispersal pattern is $63 \%$ and that of magistral pattern is $37 \%$ (Cunnigham et al.). In the present study, the incidence of both pattern in the Indian population is similar to the above finding.

It is noted that certain anatomic characteristic such as pattern of branching, number of primary divisions of arteries and veins are determined at an earlier stage of development. After determination of these characteristics, the parameters differentiate in response to functional demands, stresses and strains in subsequent developmental periods (Bhargava \& Raja). Some authors hold the view that no relationship exist between vascular pattern of chorionic blood vessels of placenta and development of foetus (Wilkins; Smart). In another study, it is observed that there is significant relationship between pattern of branching, number of primary division of arteries and weight of the foetus (Bhargava \& Raja; Shordania; Bacsich \& Crawford). In present study, it is observed that there is significant relationship between the vascular pattern and birth weight of the 
neonate. It is higher in magistral pattern in comparison to dispersal pattern in both the sexes. It may be due to better blood flow upto periphery in magistral pattern as the caliber of chorionic blood vessels is considerably same to whole extent. So, the foetus might be getting better nourishment and oxygen for the growth.

VERMA, R.; PRASAD, R.; MISHRA, S. \& KAUL, J. M. Patrón vascular de los vasos sanguíneos coriónicos de la placenta y su correlación con el peso al nacer del recién nacido. Int. J. Morphol., 30(3):952-955, 2012.

RESUMEN: Doscientas placentas de término de gravidez normales frescas fueron recogidas del departamento de Obstetricia y Ginecología, RIMS, Ranchi, Jharkhand, India. Se observó la incidencia del patrón vascular de los vasos sanguíneos coriónicos de la placenta y la relación entre el patrón vascular de ésta y el peso al nacer del recién nacido. Se inyectó tinta dentro de los vasos umbilicales bajo presión fisiológica normal, y se tomaron los diámetros de los vasos sanguíneos coriónicos en el centro y la periferia. Dos tipos de patrón vascular coriónicos se observaron en la placenta, disperso y magistral. El patrón disperso se encontró en el 63\% de los casos y el patrón magistral se observó en 37\% de los casos. Una observación interesante mostró que el peso al nacer de los recién nacidos fue mayor en el patrón magistral en comparación con el patrón disperso en ambos sexos.

PALABRAS CLAVE: Placenta; Patrón vascular; Vaso sanguíneo coriónico, Peso al nacer; Recién nacido.

\section{REFERENCES}

Bacsich, P. \& Crawford, J. M. On the probably genetic character of human placental types with some remarks on the structure of placental cotyledons. J. Anat., 94(3):449, 1960.

Bacsich, P. \& Smout, C. F. V. Observations on the foetal vessels of human placenta, with an account of the corrosion technique. J. Anat. (London), 72:358-64, 1938.

Bhargava, I. \& Raja, P. T. An anatomical study of foetal blood vessels on the chorial surface of human placenta. Acta Anat. (Basel), 75(1):13-26, 1970.

Cunnigham, F. G.; Gant, N. F.; Leveno, K. J.; Gilstrap, L. C.; Hauth, J. C.; \& Wenstrom, K. D. Physiology of Pregnancy, Placenta \& Foetal membranes. Williams Obstetrics 21st ed. Newyork, McGraw Hill Inc, 2001. pp.109-28.

Franken, H.; Florange, W. \& Hoer, F. W. Annales Universitatis Saraviensis. Medizin, 6(1):1-6, 1958.

blood vesselson the chorial surface of human placenta, Part 1 in normal pregnancy anFrazer, J. Placental circulation. Am. J. Obstet. Gynec., 6:645-55, 1923.

Park, K. Park's Health Information and Basic Medical Statistics.Parks Textbook of Preventive and Social Medicine. $17^{\text {th }}$ ed. Jabalpur, Banarsidas Bhanot Publisher, 2002. pp.60417.

Schordania, J. Uber das Gefassystem der Nabelschnur. Anat. U. Entwicklgsch., 89:696-726, 1929.

Smart, P. J. Some observations on the vascular morphology of the foetal side of the human placenta. J. Obstet. Gynaecol. Br. Emp., 69:929-33, 1962.

Wilkins, P. Contribution à l'etude de la circulation placentaire d'origine foetale. Gynéc Obstet., 53:239-63, 1954.

\author{
Correspondence to: \\ Dr. Ranjana Verma \\ 244/96, Type II Quarter \\ Mirdard Lane Residential Complex \\ Maulana Azad Medical College \\ New Delhi-110002 \\ INDIA
}

Phone Number 919868640969 919312828083

E-Mail: abharanjana@yahoo.com

Received: 14-07-2012

Accepted: 27-07-2012 